\title{
Modeling Critical Forest Habitat in the Southern Coal Fields of West Virginia
}

\author{
Aaron E. Maxwell, ${ }^{1}$ Michael P. Strager, ${ }^{2}$ Charles B. Yuill, ${ }^{2}$ and J. Todd Petty ${ }^{3}$ \\ ${ }^{1}$ Natural Resource Analysis Center, West Virginia University, Morgantown, WV 26506, USA \\ ${ }^{2}$ Division of Resource Management, West Virginia University, Morgantown, WV 26506, USA \\ ${ }^{3}$ Division of Forestry and Natural Resources, West Virginia University, Morgantown, WV 26506, USA
}

Correspondence should be addressed to Michael P. Strager, mstrager@wvu.edu

Received 14 October 2011; Accepted 2 January 2012

Academic Editor: Bradford Hawkins

Copyright (c) 2012 Aaron E. Maxwell et al. This is an open access article distributed under the Creative Commons Attribution License, which permits unrestricted use, distribution, and reproduction in any medium, provided the original work is properly cited.

Throughout the Central Appalachians of the United States resource extraction primarily from coal mining has contributed to the majority of the forest conversion to barren and reclaimed pasture and grass. The loss of forests in this ecoregion is significantly impacting biodiversity at a regional scale. Since not all forest stands provide equal levels of ecological functions, it is critical to identify and map existing forested resources by the benefits that accrue from their unique spatial patterns, watershed drainage, and landscape positions. We utilized spatial analysis and remote sensing techniques to define critical forest characteristics. The characteristics were defined by applying a forest fragmentation model utilizing morphological image analysis, defining headwater catchments at a 1:24,000 scale, and deriving ecological land units (ELUs) from elevation data. Once critical forest values were calculated, it was possible to identify clusters of critical stands using spatial statistics. This spatially explicit method for modeling forest habitat could be implemented as a tool for assessing the impact of resource extraction and aid in the conservation of critical forest habitat throughout a landscape.

\section{Introduction}

Forests provide many benefits to society and the natural environment that include providing wildlife habitat [1], maintaining biodiversity [2], regulating climate and providing carbon storage $[3,4]$, nitrogen cycling $[5,6]$, and altering and moderating hydrologic function, including evapotranspiration rates and surface runoff volumes [7]. Society land use needs and resource extraction often result in the loss of forested land cover, leading to an impact on biodiversity from habitat conversion [8-10]. In reference to forest and biodiversity conservation, there has been a shift in focus from rare or endangered species management to ecosystem and landscape scale management in which the health and function of the ecosystem as a whole is considered [11]. This focus requires that a diversity of ecological processes be considered, such as the health and structure of the forest [11]. The need is to focus on conservation of habitat richness and biodiversity at the landscape-level.
Conservation efforts should be directed at spatially explicit, landscape-level attributes, such as minimizing structural contrast between adjacent landscape units [12]. The goal of this paper was to implement such a methodology in analyzing the conservation of biodiversity and forest habitat in the Southern Coal Fields of West Virginia.

We have expanded on previous work by suggesting and implementing a methodology that allows for the indexing of critical forest stands on a pixel-by-pixel basis relative to fragmentation patterns, watershed drainage, and landscape position. We implemented a methodology for extracting highresolution, spatially explicit forest cover and disturbance data from National Agricultural Imagery Program (NAIP) orthophotography using object-based image classification and ancillary datasets. A fragmentation model utilizing morphological image analysis was then applied to the land cover data after Vogt et al. [13] to obtain high-resolution forest fragmentation data. These data were then related to watershed and landscape position in order to index forest pixels relative 
to importance of conservation for terrestrial habitat and biodiversity conservation within the region. An objective was to implement a spatial analysis method that utilized high-resolution data to describe the distribution and patterns of forest stands critical to biodiversity as a potential tool for evaluating and mitigating the effect of resource extraction in this unique and biodiverse landscape.

\section{Background}

Not all forest stands are equal in terms of crucial habitat. Wickham et al. [14] documented the importance of core or interior forests in Southern Appalachia. Core and fragmented forests differ in terms of structure, composition, and ecological processes. Edge forests have higher rates of atmospheric decomposition [15] and higher proportions of exotic species [16]. In addition, it has been determined that the amount of forest cover is positively correlated with forest breeding bird populations [17]. Habitat edges have an influence on ecological function, including biogeochemical nutrient transport [18] and species interactions [19, 20]. Edges impact ecological mechanisms, patterns, and dynamics at variable spatial scales [21], including the landscape scale [22]. Fragmentation is of critical concern when modeling processes at the landscape scale [16].

Meyer et al. [23] documented the importance of headwater reaches. Such areas within a watershed contribute to overall biodiversity in a watershed, provide refuge from predators, competitors and alien species, and serve as links to adjacent watersheds. The unique conditions of an individual headwater reach contribute to the heterogeneity of the entire watershed and landscape and enhance biodiversity [24]. Appalachia supports $10 \%$ of the global salamander and freshwater mussel diversity $[25,26]$, and their diversity is high in headwater streams [27].

Strausbaugh and Core [28] documented the unique cove hardwoods or mixed mesophytic forests that support a wide range of species in Appalachia, such as a host of arachnid species $[29,30]$. These communities are highly productive due to high moisture and fertile soil [31]. Cove hardwood forests are species rich $[32,33]$, and loss and fragmentation of these communities influence habitat suitability and potentially the persistence of the species on the landscape [31].

Weakland and Wood [34] and Wood et. al. [35] documented the importance of upland, core forest for preservation and protection of the Cerulean Warbler, a species of concern that is threatened by habitat perturbations [34, $36,37]$. As a result, we argue that forest fragmentation patterns, watershed position, and landscape position have an influence on how critical a forest stand is in terms of habitat conservation.

The Southern Coal Fields of West Virginia provides large expanses of temperate deciduous forest that are rare worldwide and provide for biodiversity [14]. For example, the eastern deciduous forest supports a wide variety of avian and large carnivore species; however, the extent and fragmentation of the forest have a direct impact on species abundance and composition [38]. In the temperate zone, the southern
Appalachian region is among the highest in biodiversity and endemism with more than 2,000 documented vascular plant species and the highest freshwater biodiversity in North America [25, 39]. In the Southern Coal Fields of Appalachia, it has been suggested that increased seasonality of climate during the transition from glacial to interglacial conditions in the late Pleistocene and Holocene induced landscape instability that resulted in a heterogeneous mosaic of habitats [40]. This resulted in the rich and diverse biota observed today, and environmental changes can have a significant impact on the survival of species that have adapted to such specific conditions [40]. Southern Appalachian forests can be characterized as spatially extensive interior forests, and the extent of forest and its spatial patterns and distribution have been shown to have a direct influence on habitat suitability [41-43].

Land use and land disturbance impact forest extent, composition, and spatial patterns, which have consequences for biodiversity and other environmental services $[44,45]$. Surface mining, and specifically mountaintop removal with valley fills (MTR/VF), is currently the leading cause of land cover and land use change in the Southern Coal Fields of West Virginia [46-49]. MTR/VF consists of clearing upland forests, removing top soil, and blasting away overburden rock material to extract coal seams. Overburden material is often placed in adjacent valleys, filling headwater steam segments. Land cover, landscape contours, and surface flowpaths are altered [24]. Multiple watersheds in West Virginia have more than $10 \%$ of their surface area disturbed by surface mining [50]. The mining processes often results in a conversion of forested land cover to barren land cover. Later reclamation produces grasslands on the topographically altered mountaintops; however, productivity of the grasslands is often low due to poor soil conditions [51]. It has been estimated that all surface mining in Appalachia has resulted in a net loss of 420,000 ha of forest [48].

Wickham et al. [14] suggest that the amount of interior forest lost is greater than the amount of forest lost resulting from direct conversion of forest to surface mines. Forests loose interior character by the introduction of nonforest edges. Thus, the influence of surface mining extends into adjacent forest due to edge effects, and the spatially extensive nature of the forest is interrupted. Weakland and Wood [34] and Wood et al. [35] found that MTR/VF mining alters the spatial configuration of forested habitats, creating edge and area effects that negatively affect Cerulean Warbler abundance and occurrence on the landscape.

\section{Study Area}

The study area for this project is a 2,280,423 ha area that encompasses the Southern Coal Fields of West Virginia (Figure 1). This area was defined relative to hydrologic unit code (HUC) 8 boundaries that intersect the MTR/VF region in West Virginia.

The study area exists within the Appalachian Plateau physiogeographic province, a dissected, westward-tilted plateau dominated by Pennsylvanian bedrock. Pennsylvanian stratigraphy is characterized as cyclic sequences of sandstone, 
shale, clay, coal, and limestone [52]. The terrain is dissected by a dendritic stream network and shows fine texture with moderate-to-strong local relief. In comparison to the northern Appalachian Plateau, the Southern Coal Fields is generally more rugged due to resistant strata. Precipitation levels, temperature, and terrain allow for a variety of forest communities to flourish including oak-pine, oak-chestnut, cove hardwoods or mixed mesophytic forests, and floodplain communities [28]. Although surface mining has altered this landscape, it is still predominantly forested, in contrast to other regions of the eastern United States that have experienced development $[46,47]$.

\section{Methodology}

Indexing critical forest habitat incorporated several remote sensing image classification and spatial analysis processes. First, high-resolution land cover was extracted using objectbased feature extraction and GIS decision rules. Objectbased image classification allowed for the creation of high-resolution land cover/land use data from available aerial imagery. Second, a high-resolution forest fragmentation model was created for the region using a model developed by Vogt et al. [13]. Third, small catchment areas relative to $1: 24,000$ scale stream segments were extracted and headwater catchments were identified. And lastly, we incorporated digital elevation model (DEM) data at $1: 4,800$ scale to produce ecological land units (ELUs) for a thematic map representation of landforms. These products were then combined to describe critical forest habitat relative to fragmentation, watershed position, and landscape position.

4.1. Extraction of Land Cover/Land Use Data. Land cover/ land use was produced utilizing an object-based feature extraction process along with decision rules. NAIP imagery was collected during leaf-on conditions in 2009 and made available in October 2009. The imagery has a $1 \mathrm{~m}$ nominal pixel spacing, a scale of $1: 10,000$, and is rectified to a horizontal accuracy of within \pm 5 meters of reference digital ortho quarter quads from the National Digital Ortho Program. This imagery was classified and results were merged to produce a continuous thematic dataset for the region.

Feature Analyst 4 by Visual Learning Systems (VLSs) within Erdas Imagine 9.3 was utilized to extract the following land cover types: barren/developed, grasslands, and forest. This software tool examines both the spectral and textural information within the imagery to produce thematic map data. As a result, unlike supervised classification techniques, feature extraction classifies an image using more than just the digital number $(\mathrm{DN})$ or spectral information contained by each pixel. Spatial context information such as spatial association, size, shape, texture, pattern, and shadow are considered [53]. Studies have shown that feature extraction or objected-based algorithms are more effective and accurate at extracting information from high-resolution imagery than traditional image classification methods, such as supervised classification, because additional image characteristics are considered such as spatial context [54-57]. Feature extraction takes into account the spatial context that is available

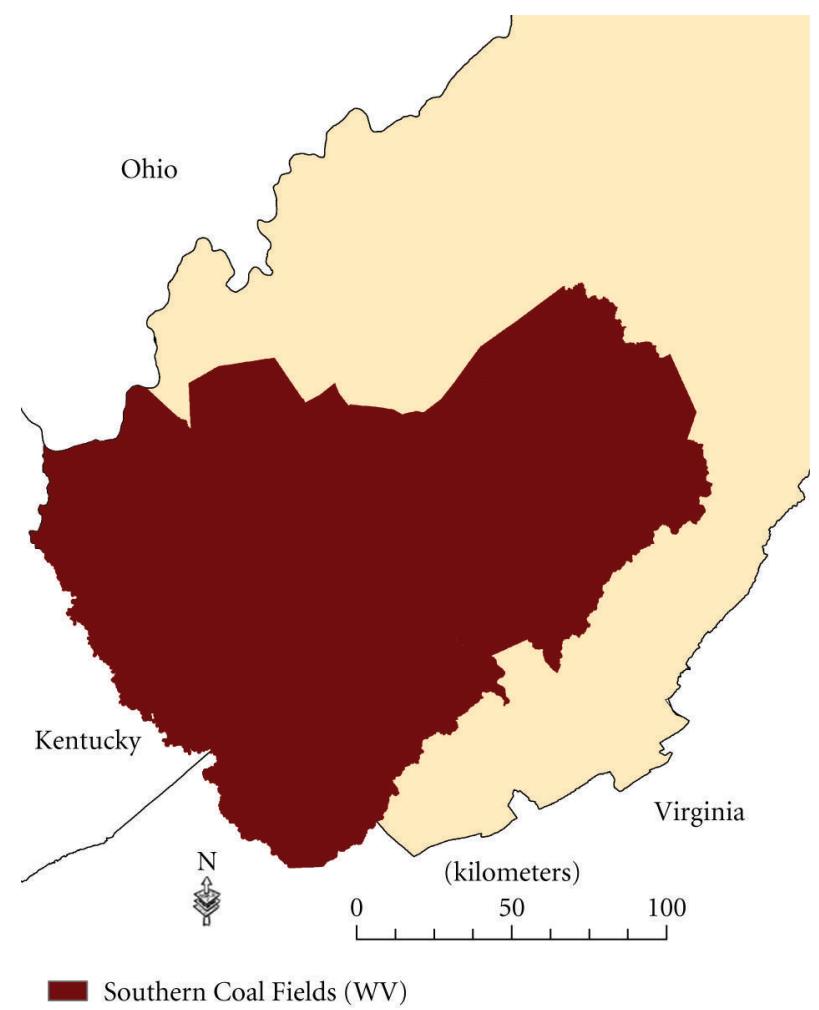

Figure 1: Study area. Southern Coal Fields of West Virginia.

in high-resolution imagery, such as NAIP orthophotography. Due to the high spatial resolution and reduced spectral resolution of NAIP orthophotography in comparison to satellite imagery traditionally used to obtain thematic map data, we used feature extraction as the classification approach in order to make use of the spatial context and textural information contained in the imagery.

User-assisted feature extraction requires user-defined knowledge, as training data, to recognize and classify target features in an image [58]. As a result, we collected training samples as polygons by manually interpreting the imagery. For example, for a single dataset, we collected 101 examples of barren/developed land cover, 165 examples of grasslands land cover, and 147 examples of forested land cover. Our goal was to provide training data that accurately described the spectral and textural signature and variability of the land cover of interest.

An error assessment was performed by comparing the thematic map results to manual interpretation of the imagery at randomly selected locations. This assessment predicted $88 \%$ producer's accuracy and $99 \%$ user's accuracy for the forest class. As a result, this method allows for an accurate differentiation of forested land cover utilizing NAIP imagery to provide a recent and high spatial resolution representation of land cover and forest extent. It should be noted that datasets can be updated as new imagery is collected; for example, NAIP imagery has been collected in West Virginia in 2007, 2009, and 2011, which is a true benefit of utilizing NAIP. It is publically available, high-resolution data and is commonly flown every two years. 


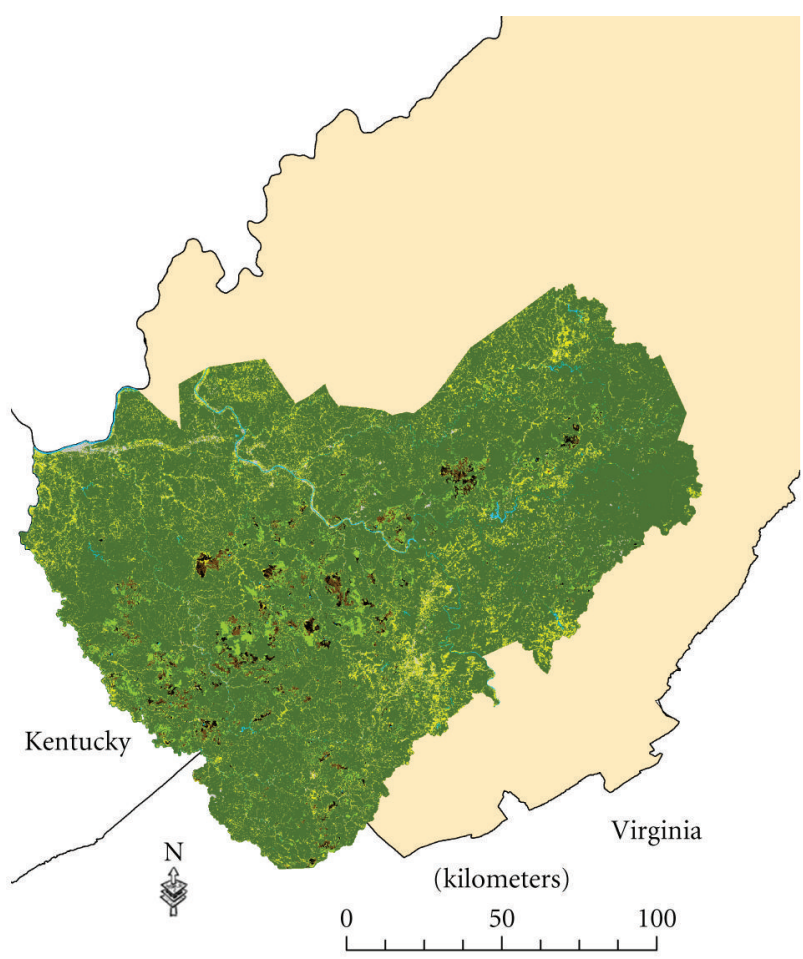
Forested
Grasslands/pastureland/agricultural land
Barren/developed
Forested in permit (not disturbed)
Grasslands in permit (potentially reclaimed)?
Barren in permit (potentially active mining or not yet reclaimed)?
Open water

Figure 2: Land cover/land use data from object-based image classification of NAIP orthophotography.

To further differentiate the land cover, we incorporated ancillary GIS data. Surface mine permit data from the West Virginia Department of Environmental Protection (WVDEP) were utilized to extract barren and grassland land cover that resulted from surface mining. For example, if barren land cover existed within a permit, it was determined to be a result of mining. This method allowed us to obtain an estimate of the area that is currently permitted but is still forested, and this classification represents areas on the landscape that have a higher potential for future disturbance relative to areas outside of surface mine permits.

This feature extraction and decision rule method allowed for the development of a high-resolution land cover dataset for the region relative to leaf-on 2009 conditions. Figure 2 describes the resulting land cover.

4.2. Forest Fragmentation Model. The land cover data were reclassified as a binary forest/nonforest raster. The data were resampled using bilinear interpolation to a $9 \mathrm{~m}$ cell size to match the topographic data. Morphological image processing was applied to extract forest fragmentation data. The

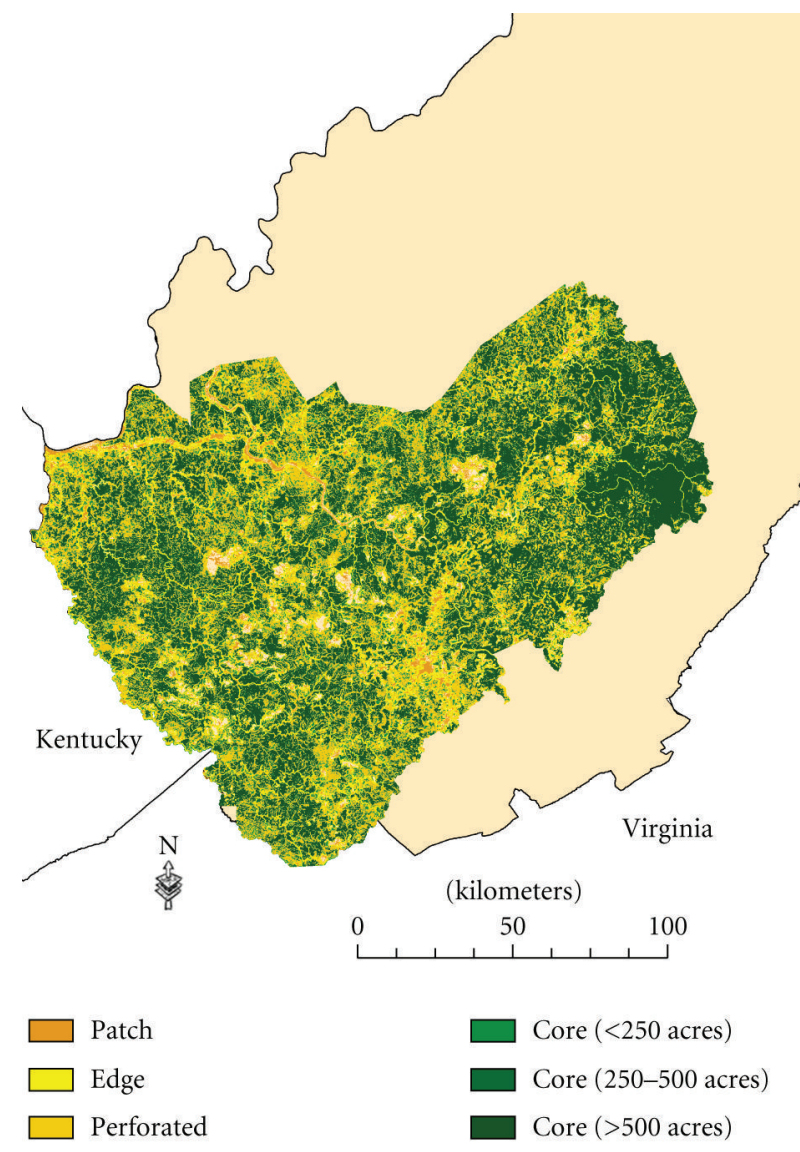

Figure 3: Fragmentation model after Vogt et al. [13].

methodology is described in detail by Vogt et al. [13]. Morphological image processing uses mathematical morphology to analyze shape and form of objects [13]. Forest pixels are classified as patch, edge, perforated, or core using this model. This method has been shown to provide a more accurate representation of fragmentation at the single pixel or landscape level when compared to image convolution [13]. Figure 3 shows the fragmentation model.

4.3. Defining Watershed Position. Headwater watersheds were produced at a 1:24,000 scale as described by Strager et al. [59]. The high-resolution National Hydrologic Dataset (NHD) stream segments were extracted and catchments delineated for all stream segments using DEM data. Photogrammetrical elevation data from $1: 4,800$ scale were interpolated to a $3 \mathrm{~m}$ and then $9 \mathrm{~m}$ scale. Stream segment pour points were compared to a flow direction grid to obtain the catchment areas.

The high-resolution NHD data have tabulated flow networks and connectivity information for each segment, to delineate headwater reaches. These are reaches that do not collect drainage from upstream. As a result, the headwater catchments in this project are $1: 24,000$ scale catchments derived by comparing high-resolution NHD data to DEMs and were defined as catchments collecting no upstream drainage. 


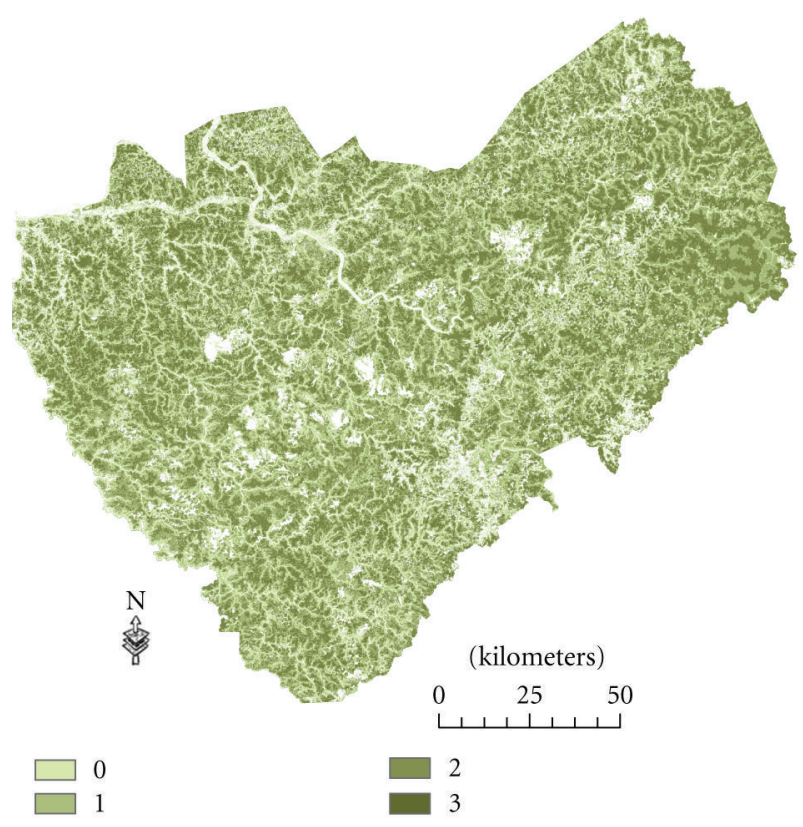

Figure 4: Critical forest model for Southern Coal Fields of West Virginia.

4.4. Modeling Landscape Position. The $9 \mathrm{~m}$ DEM data for the region, resampled from $3 \mathrm{~m}$, was used to classify the terrain into the following ecological land units (ELUs): cliff, steep slope, slope crest, upper slope, flat summit, sideslope, cove, dry flat, moist flat, wet flat, and slope bottom. The methodology described by Anderson et al. [60] provides a means to utilize DEM data to classify the landscape into different units of ecological significance. DEM derivatives were created including slope in degrees, a hydrologically filled DEM, flow direction, and flow accumulation within GIS. The slope and flow accumulation grids were utilized to calculate a moisture index. The moisture index is a relative measure of the moisture of a specific cell, and it assumes that the moisture level is a function of how much water flows into the cell, predicted by flow accumulation, and how fast the water can flow out, described by slope [61-66].

Landscape position was calculated following Fels and Zobel [67], by dividing the landscape into the following categories: ridge, wide ridge, and slope/flat, slope/cove. The approach is based on a local neighborhood analysis in which a cell is compared to its neighbors. This method is based on distance-weighted assessment of elevation values in which a cell is compared to the mean elevation of all values within search windows of different sizes and extents. Landscape position was combined with slope and moisture index data to derive the ELU classes.

Once the ELU data were created, certain classes were selected as critical for our model. This included upland areas (slope crest and flat summit) and coves. This provided two mutually exclusive positions upon the landscape that were considered critical for biodiversity.

4.5. Critical Forest Model. The critical forest model was created by combining the core forest, forest in headwater

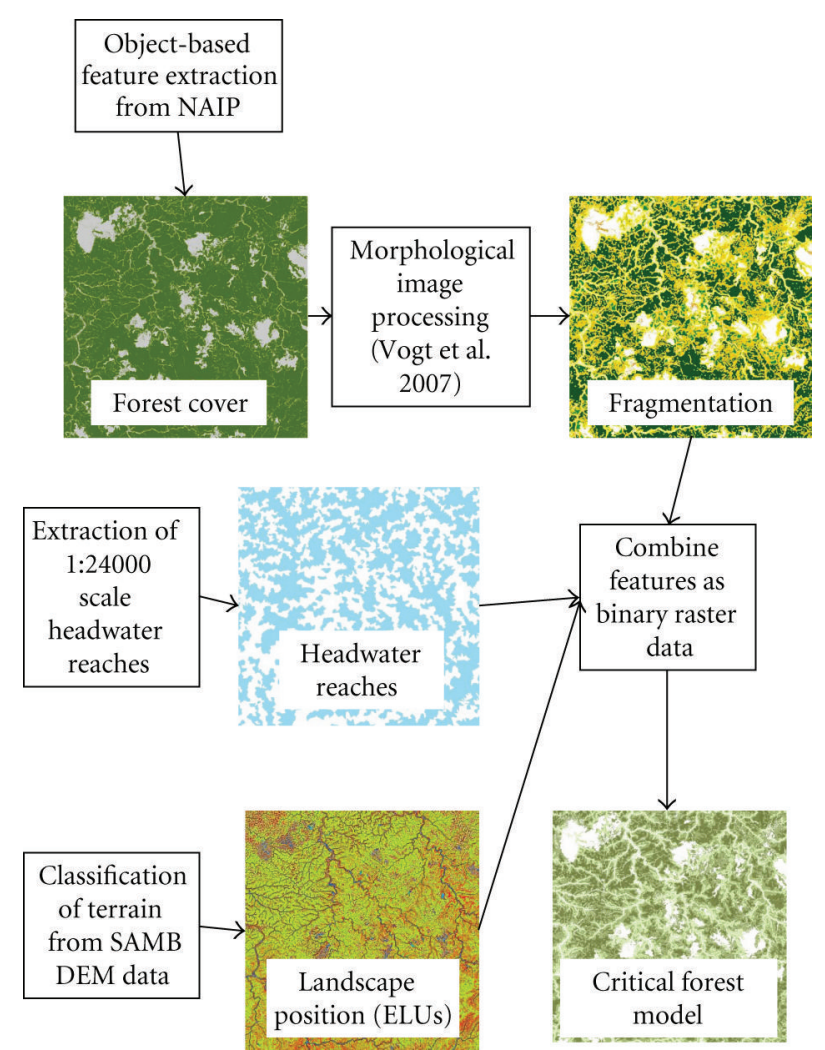

Figure 5: Flow chart for critical forest model creation.

catchments, cove forests, and upper slope forests. These layers were combined as binary raster layers to produce an index grid. Possible values ranged from 0 (not critical) to 3 (most critical). As the model was defined, cove and upper slope forests could not overlap, so the maximum index possible was 3. As a result, the final result of the analysis was an index grid that combines forest fragmentation, watershed position, and landscape position to describe forest critical for habitat and biodiversity at a $9 \mathrm{~m}$ pixel scale. The final output is shown in Figure 4. Figure 5 describes the overall process for the creation of the critical forest model.

Once the critical forest model was produced, we summarized the data relative to HUC (Hydrologic Unit Code) 8 and 11 catchments. We also assessed the data for spatial clustering using cluster and outlier analysis (Anselin Local Morans I) in GIS. Areas of surface mining, both active mining and reclamation, were converted to forested land cover, and the analysis was repeated using the potential premining land cover to analyze the distribution of premining critical forest habitat.

\section{Results}

5.1. Land Cover/Land Use and Forest Fragmentation. The land cover/use for the entire study area extent is summarized in Table 1. Although this landscape has been heavily surface mined (contributing 3\% of the land cover/land use), forest is still the dominant cover type ( $86.1 \%$ of the land cover); however, $3.2 \%$ of the landscape has been permitted for mining, 
TABLE 1: Land cover/land use data for study area.

\begin{tabular}{lcc}
\hline Land cover/land use & Hectares & Percentage \\
\hline Forested & $1,892,774$ & $82.9 \%$ \\
Grasslands/pastureland/agricultural land & 172,316 & $7.5 \%$ \\
Barren/developed & 54,770 & $2.4 \%$ \\
Forested in permit (not disturbed) & 72,505 & $3.2 \%$ \\
$\begin{array}{l}\text { Grasslands in permit (potentially } \\
\text { reclaimed) }\end{array}$ & 44,314 & $1.9 \%$ \\
$\begin{array}{l}\text { Barren in permit (potentially active mining } \\
\text { or not yet reclaimed) }\end{array}$ & 25,621 & $1.1 \%$ \\
Open water & 20,318 & $0.9 \%$ \\
\hline
\end{tabular}

TABle 2: Land cover/land use data for the Coal River Watershed.

\begin{tabular}{lcc}
\hline Land cover/land use & Hectares & $\begin{array}{c}\text { Percentage of } \\
\text { watershed }\end{array}$ \\
\hline $\begin{array}{l}\text { Forested } \\
\text { Grasslands/pastureland/agricultural }\end{array}$ & 168,420 & $73.0 \%$ \\
land & 1,6420 & $7.1 \%$ \\
$\begin{array}{l}\text { Barren/developed } \\
\text { Forested in permit (not disturbed) }\end{array}$ & 4,140 & $1.8 \%$ \\
$\begin{array}{l}\text { Grasslands in permit (potentially } \\
\text { reclaimed) }\end{array}$ & 12,760 & $8.7 \%$ \\
$\begin{array}{l}\text { Barren in permit (potentially active } \\
\text { mining or not yet reclaimed) }\end{array}$ & 7,640 & $3.5 \%$ \\
Open water & 1,310 & $0.6 \%$ \\
\hline
\end{tabular}

TABLE 3: Critical forest index distributions.

\begin{tabular}{lcccc}
\hline \multirow{2}{*}{ Index } & \multicolumn{2}{c}{ Study area } & \multicolumn{2}{c}{ Forest in Permit } \\
& Hectares & Percentage & Hectares & Percentage \\
\hline 0 & 351,924 & $17.7 \%$ & 14,406 & $21.5 \%$ \\
1 & 819,975 & $41.3 \%$ & 35,768 & $53.3 \%$ \\
2 & 670,289 & $33.8 \%$ & 15,305 & $22.8 \%$ \\
3 & 143,474 & $7.2 \%$ & 1,596 & $2.4 \%$ \\
\hline
\end{tabular}

but is currently not disturbed (forested). As a result, mine expansion is likely to induce further land cover change and loss of forest over large extents.

The landscape disturbance is not evenly distributed throughout the region. Table 2 describes the land cover distribution for the Coal River HUC 8 watershed. According to our land cover calculations, $8.8 \%$ of the watershed is disturbed by active mining or reclamation while an additional $8.7 \%$ has been permitted but has not yet been disturbed or is still forested. The dominant land cover type in this watershed is forest; however, landscape disturbance due to surface mining is a dominant land use feature.

Of the forested land cover within the region, 51\% was predicted as core forest using the Vogt et al. [13] model, $38.1 \%$ was classified as perforated, $9.2 \%$ as edge, and $1.2 \%$ as patch. Of the core forest, the majority of the pixels were
TABLE 4: Critical forest index distribution in mined areas.

\begin{tabular}{lcc}
\hline Value & Hectares & Percentage \\
\hline 0 & $61,949.7$ & $9.3 \%$ \\
1 & $222,677.1$ & $33.4 \%$ \\
2 & $296,801.1$ & $44.5 \%$ \\
3 & $84,903.3$ & $12.7 \%$ \\
\hline
\end{tabular}

within large core extents, greater than 500 acres. Forested areas currently in permits were predicted as dominantly being edge and perforated forest explained possibly by the adjacency to active mine sites and reclamation or small forest stands surrounded by reclamation.

5.2. Critical Forest Model. Table 3 shows the distribution of critical forest index values throughout the region and only within the permitted forested areas. Based on visual interpretation of the results, the most critical areas as defined by the model are either cove or upper slope core forests within headwater reaches. As can be seen in Table 1, it was very common for a pixel to satisfy at least one of the criteria.

The data were summarized relative to HUC 8 and HUC 11 watershed that intersect the MTR/VF region and exist entirely within West Virginia. This data suggests that The Elk River HUC 8 watershed has the highest percentage of critical forest value pixels (values 1 through 3 ) within the MTR/VF region of West Virginia. At the HUC 11 scale, we found that local, spatial clusters of watersheds exist when the percentage of critical forest is considered.

Perhaps a more useful representation of spatial clustering for land management and regulation purposes would be the stand scale throughout the landscape as opposed to large catchment areas. We smoothed the raster critical forest model using majority filter operations within GIS then converted contiguous areas of a single critical forest value to polygon features, and a cluster and outlier analysis of these areas was performed relative to area of the polygons and critical forest value. This showed that clusters of critical forest areas exist across the landscape, especially when value 3 areas are of interest. Clusters of critical forest stands could represent areas that should be managed or protected in order to preserve biodiversity throughout the landscape and region.

Table 4 describes the distribution of critical forest values in areas of mine disturbance and it offers an estimate of the critical nature of mine disturbed areas based on the assumption that these areas were forested on the premining landscape, which we argue is a valid assumption based on comparisons to premining satellite data and the landscape position of the mines. Figure 6 offers a comparison of preand postmining conditions. This data suggests that critical forest areas overlap with areas of resource extraction. It has been documented that mining impacts headwater catchments and upland terrains, which are critical for biodiversity $[14,24,35]$. This data suggests that there is a need to delineate stands and clusters of critical forests habitats throughout the region because they are being deforested and impacted by resource extraction. 


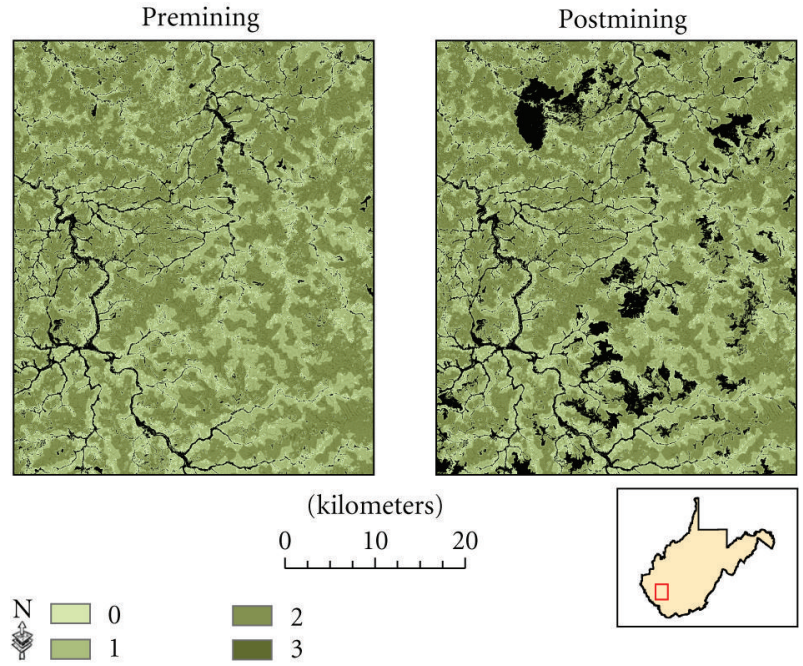

FIgURE 6: Pre- and postmining critical forest habitat.

\section{Discussion}

Our critical forest modeling is based on that all forest stands are not equal in terms of habitat suitability and supporting biodiversity. By taking into account high-resolution forest fragmentation patterns, watershed position, and landscape position, forest pixels were indexed relative to these factors that have an impact on habitat. Continued surface mining in the region will likely continue to alter forests, habitats, and the ecosystem and landscape as a whole, and this practice has been shown to produce both aquatic and terrestrial habitat degradation $[24,50]$. Perhaps considering not just the extent of forest to be disturbed, but the ecological function of the forest, is necessary when continued mining and forest disturbance are proposed. Perhaps certain forests, such as core, headwater, cove forests, should be protected over other forested areas that are not as ecologically valuable. As resource extraction continues, perhaps regulators should take into account such abiotic factors of the landscape and adjust practices to minimize disturbance of critical areas. Perhaps spatial clusters of critical forest habitat should be considered during the permitting process.

We argue that a spatially explicit and high-resolution means of classifying or indexing critical forest stands is valuable as a regulatory tool for assessing the impact of continued mining and resource extraction in this region. McDermid et al. [68] suggest that remote sensing and GIS data that consider multiple attributes for modeling wildlife habitat are valuable, especially for large study areas. They also highlighted the use of land cover derived from object-based image classification, as was performed here. Their study focused on explaining patterns of grizzly bears habitat use within a study area in Alberta, Canada, and they found that incorporating data beyond categorical land cover was superior for their modeling purposes. Currently, there is a lack of guidelines for the selection and analysis of spatial data for exploring environmental and ecological questions [68]. We suggest that considering forest fragmentation (a derivative of land cover) along with catchment and terrain-derived variables provided a better understanding of critical habitat in the Southern Coal Fields of West Virginia than could be obtained utilizing land cover alone.

Optimal spatial resolution of thematic map data for a region of this extent and for this mapping purpose is debatable. As an example, Landsat MSS data, offering a $60 \mathrm{~m}$ pixel, has been shown to be inadequate for urban mapping; also, as a general rule a pixel should be at least one-half the size of the shortest dimension of the smallest feature that is being mapped [69]. Our aim was to describe the forest cover at a stand level and to map disturbance features with small spatial extents that interrupt the canopy. As a result, a finer resolution dataset was required than what Landsat Multispectral Scanner (MSS) or Thematic Mapper (TM) data could offer; as a result, NAIP imagery and object-based classifiers were utilized to obtain the base thematic map data from which the forest cover and forest fragmentation were derived. Now that object-based image classification tools are available and high-resolution land cover and forest cover can be extracted from high-resolution and low spectral resolution imagery, forest cover data at the stand scale may become more widely available. We note that there is value in including such data in environmental modeling and assessment practices and combining that data with other datasets, such as topographic data, to model multiple attributes of the landscape.

Forest alteration resulting from mountaintop mining may not be characteristic of other human land use practices that result in deforestation, such as agriculture. Generally, forest cover change is most common in areas of low elevation and gentle terrain [70]. Mountaintop mining often induces land cover change in upland areas, headwater reaches, and rugged terrains $[24,35]$. As a result, there is a need to understand the critical nature of these upland forests in order to assess the environmental impact of mountaintop mining, which produces unique landscape alteration.

Critical forest habitat modeling may also be useful in other landscapes impacted by resource extraction. For example, extraction of natural gas from the Marcellus Shale Formation throughout parts of New York, Pennsylvania, West Virginia, and Maryland in the eastern United States could contribute to habitat fragmentation and alteration of forest extents as access roads and well pads are established [71]. High-resolution land cover, fragmentation, watershed, and terrain data could be used to model the impact and predict critical habitats using similar methodology as proposed here.

\section{Conclusion}

We have presented a method for indexing of critical forest stands on a pixel-by-pixel basis relative to fragmentation patterns, watershed drainage, and landscape position. This methodology was implemented throughout the Southern Coal Fields of West Virginia and could be applied in other regions impacted by resource extraction. It relies on high-resolution spatially explicit forest cover from NAIP imagery using object-based feature extraction, creating a forest fragmentation model after Vogt et al. [13] utilizing 
morphological image analysis, defining headwater catchments at a $1: 24,000$ scale, and extracting ecological land units (ELUs) from DEM data. Once critical forest values are calculated, it is possible to identify spatial clusters of critical stands. This spatially explicit method for modeling forest habitat could be implemented as a tool for assessing the impact of resource extraction and aid in the conservation of critical habitat.

Future research should focus on incorporating additional landscape variables to model and differentiate forest stands. For example, canopy height data derived from LiDAR (light detection and ranging) could provide additional forest metrics for modeling. Additional pattern and connectivity analysis may provide for a better understanding of the network of critical forest stands throughout the region.

Our goal was to present a remote sensing and GIS method for indexing forest pixels throughout a disturbed landscape and was based on the assumption that all forests are not equal in terms of habitat. As resource extraction continues throughout the region, considering the nature of the forest to be disturbed may aid in mitigating environmental impacts of human land use.

\section{References}

[1] D. D. Chiras, J. P. Reganold, and O. S. Owen, Natural Resource Conservation, Prentice Hall, Upper Saddle River, NJ, USA, 8th edition, 2002.

[2] T. E. Lovejoy, R. O. Bierregaard, A. B. Rylands et al., "Edge and other effects of isolation on Amazonian forest fragmentation," in Conservation Biology: The Science of Scarcity and Diversity, M. Soule, Ed., pp. 257-285, Sinauer Associates, Sunderland, Mass, USA, 1986.

[3] R. R. Nemani and S. W. Running, "Satellite monitoring of global land cover changes and their impact on climate," Climatic Change, vol. 31, no. 2-4, pp. 395-413, 1995.

[4] R. A. Houghton, J. L. Hackler, and K. T. Lawrence, "The U.S. carbon budget: contributions from land-use change," Science, vol. 285, no. 5427, pp. 574-578, 1999.

[5] P. M. Vitousek, J. D. Aber, R. W. Howarth et al., "Human alteration of the global nitrogen cycle: sources and consequences," Ecological Applications, vol. 7, no. 3, pp. 737-750, 1997.

[6] S. R. Carpenter, N. F. Caraco, D. L. Correll, R. W. Howarth, A. N. Sharpley, and V. H. Smith, "Nonpoint pollution of surface waters with phosphorus and nitrogen," Ecological Applications, vol. 8, no. 3, pp. 559-568, 1998.

[7] R. E. Dickinson, "Global change and terrestrial hydrology-a review," Tellus, vol. 43, no. 4, pp. 176-181, 1991.

[8] J. Chow, R. J. Kopp, and P. R. Portney, "Energy resources and global development," Science, vol. 302, no. 5650, pp. 15281531, 2003.

[9] A. P. Dobson, A. D. Bradshaw, and A. J. M. Baker, "Hopes for the future: restoration ecology and conservation biology," Science, vol. 277, no. 5325, pp. 515-522, 1997.

[10] W. E. Westman, "Managing for biodiversity: unresolved science and policy questions," BioScience, vol. 40, no. 1, pp. 2633, 1990.

[11] K. A. Poiani, B. D. Richter, M. G. Anderson, and H. E. Richter, "Biodiversity conservation at multiple scales: functional sites, landscapes, and networks," BioScience, vol. 50, no. 2, pp. 133$146,2000$.
[12] J. F. Franklin, "Preserving biodiversity: species, ecosystems, or landscape?" Ecological Applications, vol. 3, no. 2, pp. 202-205, 1993.

[13] P. Vogt, K. H. Riitters, C. Estreguil, J. Kozak, T. G. Wade, and J. D. Wickham, "Mapping spatial patterns with morphological image processing," Landscape Ecology, vol. 22, no. 2, pp. 171177, 2007.

[14] J. D. Wickham, K. H. Riitters, T. G. Wade, M. Coan, and C. Homer, "The effect of Appalachian mountaintop mining on interior forest," Landscape Ecology, vol. 22, no. 2, pp. 179-187, 2007.

[15] K. C. Weathers, M. L. Cadenasso, and S. T. A. Pickett, "Forest edges as nutrient and pollutant concentrators: potential synergisms between fragmentation, forest canopies, and the atmosphere," Conservation Biology, vol. 15, no. 6, pp. 15061514, 2001.

[16] K. A. Harper, S. E. MacDonald, P. J. Burton et al., "Edge influence on forest structure and composition in fragmented landscapes," Conservation Biology, vol. 19, no. 3, pp. 768-782, 2005.

[17] M. K. Trzcinski, L. Fahrig, and G. Merriam, "Independent effects of forest cover and fragmentation on the distribution of forest breeding birds," Ecological Applications, vol. 9, no. 2, pp. 586-593, 1999.

[18] J. F. Kitchell, R. V. O’Neil, D. Webb et al., "Consumer regulation of nutrient cycling," BioScience, vol. 29, no. 1, pp. 2834, 1979.

[19] P. Kareiva and G. Odell, "Swarms of predators exhibit "preytaxis" if individual predators use area-restricted search," American Naturalist, vol. 130, no. 2, pp. 233-270, 1987.

[20] J. Roland and P. D. Taylor, "Insect parasitoid species respond to forest structure at different spatial scales," Nature, vol. 386, no. 6626, pp. 710-713, 1997.

[21] T. B. Smith, R. K. Wayne, D. J. Girman, and M. W. Bruford, "A role for ecotones in generating rainforest biodiversity," Science, vol. 276, no. 5320, pp. 1855-1857, 1997.

[22] T. M. Donovan, P. W. Jones, E. M. Annand, and F. R. Thompson III, "Variation in local-scale edge effects: mechanisms and landscape context," Ecology, vol. 78, no. 7, pp. 2064-2075, 1997.

[23] J. L. Meyer, D. L. Strayer, J. B. Wallace, S. L. Eggert, G. S. Helfman, and N. E. Leonard, "The contribution of headwater streams to biodiversity in river networks," Journal of the American Water Resources Association, vol. 43, no. 1, pp. 86103, 2007.

[24] E. S. Bernhardt and M. A. Palmer, "The environmental costs of mountaintop mining valley fill operations for aquatic ecosystems of the Central Appalachians," Annals of the New York Academy of Sciences, vol. 1223, no. 1, pp. 39-57, 2011.

[25] L. L. Master, S. R. Flack, and B. A. Stein, Rivers of Life: Critical Watersheds for Protecting Freshwater Biodiversity, The Nature Conservancy, Arlington, Va, USA, 1998.

[26] N. B. Green and T. K. Pauley, Amphibians and Reptiles in West Virginia, University of Pittsburgh Press, Pittsburgh, Pa, USA, 1987.

[27] A. Clarke, R. Mac Nally, N. Bond, and P. S. Lake, "Macroinvertebrate diversity in headwater streams: a review," Freshwater Biology, vol. 53, no. 9, pp. 1707-1721, 2008.

[28] P. D. Strausbaugh and E. L. Core, Flora of West Virginia, Seneca Books, Morgantown, WVa, USA, 1977.

[29] J. A. Coddington, L. H. Young, and F. A. Coyle, "Estimating spider species richness in a Southern Appalachian cove hardwood forest," The Journal of Arachnology, vol. 24, no. 2, pp. $111-128,1996$. 
[30] F. A. Coyle, "Effects of clearcutting on the spider community of a Southern Appalachian forest," The Journal of Arachnology, vol. 9, pp. 285-298, 1981.

[31] M. G. Turner, S. M. Pearson, P. Bolstad, and D. N. Wear, "Effects of land-cover change on spatial pattern of forest communities in the Southern Appalachian Mountains (USA)," Landscape Ecology, vol. 18, no. 5, pp. 449-464, 2003.

[32] S. M. Pearson, A. B. Smith, and M. G. Turner, "Forest patch size, land use, and mesic forest herbs in the French Broad River Basin, North Carolina," Castanea, vol. 63, no. 3, pp. 382-395, 1998.

[33] C. E. Mitchell, M. G. Turner, and S. M. Pearson, "Effects of historical land use and forest patch size on myrmechocores and ant communities in the Southern Appalachian Highlands (USA)," Ecological Applications, vol. 12, pp. 1364-1377, 2002.

[34] C. A. Weakland and P. B. Wood, "Cerulean warbler (Dendroica cerulea) microhabitat and landscape-level habitat characteristics in Southern West Virginia," The Auk, vol. 122, no. 2, pp. 497-508, 2005.

[35] P. B. Wood, S. B. Bosworth, and R. Dettmers, "Cerulean warbler abundance and occurrence relative to large-scale edge and habitat characteristics," The Condor, vol. 108, no. 1, pp. 154-165, 2006.

[36] P. B. Hamel, D. K. Dawson, and P. D. Keyser, "How we can learn more about the cerulean warbler (Dendroica cerulea)," The Auk, vol. 121, no. 1, pp. 7-14, 2004.

[37] J. Jones, R. D. DeBruyn, J. J. Barg, and R. J. Robertson, "Assessing the effects of natural disturbance on a neotropical migrant songbird," Ecology, vol. 82, no. 9, pp. 2628-2635, 2001.

[38] P. A. Keddy and C. G. Drummond, "Ecological properties for the evaluation, management, and restoration of temperate deciduous forest ecosystems," Ecological Applications, vol. 6, no. 3, pp. 748-762, 1996.

[39] B. A. Stein, L. S. Kutner, and J. S. Adams, Precious Heritage: The Status of Biodiversity in the United States, Oxford University Press, New York, NY, USA, 2000.

[40] P. A. Delcourt and H. R. Delcourt, "Paleoecological insights on conservation of biodiversity: a focus on species, ecosystems, and landscapes," Ecological Applications, vol. 8, no. 4, pp. 921934, 1998.

[41] SAMAB (Southern Appalachian Man and the Biosphere), "The Southern Appalachian assessment terrestrial," Tech. Rep. Report 5 of 5, US Department of Agriculture, Forest Service, Atlanta, Ga, USA, 2008, http://www.samab.org/ saa/saa_reports.html.

[42] S. K. Robinson, F. R. Thompson III, T. M. Donovan, D. R. Whitehead, and J. Faaborg, "Regional forest fragmentation and the nesting success of migratory birds," Science, vol. 267, no. 5206, pp. 1987-1990, 1995.

[43] L. Fahrig, "Effect of habitat fragmentation on the extinction threshold: a synthesis," Ecological Applications, vol. 12, no. 2, pp. 346-353, 2002.

[44] D. J. Mladenoff, M. A. White, J. Pastor, and T. R. Crow, "Comparing spatial pattern in unaltered old-growth and disturbed forest landscapes," Ecological Applications, vol. 3, no. 2, pp. 294-306, 1993.

[45] K. H. Riitters, J. D. Wickham, R. V. O’Neill et al., "Fragmentation of continental United States forests," Ecosystems, vol. 5, no. 8, pp. 815-822, 2002.

[46] R. L. Hooke, "Spatial distribution of human geomorphic activity in the United States: comparison with rivers," Earth Surface Processes and Landforms, vol. 24, no. 8, pp. 687-692, 1999.
[47] K. L. Saylor, "Land Cover Trends Project: Central Appalachians," U.S. Department of the Interior, U.S. Geological Survey, Washington, DC, USA, 2008, http://landcovertrends .usgs.gov/east/eco69Report.html.

[48] M. A. Drummond and T. R. Loveland, "Land-use pressure and a transition to forest-cover loss in the Eastern United States," BioScience, vol. 60, no. 4, pp. 286-298, 2010.

[49] P. A. Townsend, D. P. Helmers, C. C. Kingdon, B. E. McNeil, K. M. de Beurs, and K. N. Eshleman, "Changes in the extent of surface mining and reclamation in the Central Appalachians detected using a 1976-2006 Landsat time series," Remote Sensing of Environment, vol. 113, no. 1, pp. 62-72, 2009.

[50] M. A. Palmer, E. S. Bernhardt, W. H. Schlesinger et al., "Mountaintop mining consequences," Science, vol. 327, no. 5962, pp. 148-149, 2010.

[51] J. A. Simmons, W. S. Currie, K. N. Eshleman et al., "Forest to reclaimed mine land use change leads to altered ecosystem structure and function," Ecological Applications, vol. 18, no. 1, pp. 104-118, 2008.

[52] WVGES (West Virginia Geologic and Economic Survey), "Physiographic provinces of West Virginia," 2005, http://www.wvgs.wvnet.edu/www/maps/pprovinces.htm.

[53] D. Opitz, "An automated change detection system for specific features," in Proceedings of the International ESRI User Conference, Environmental Systems Research Institute, San Diego, Calif, USA, July 2003.

[54] M. A. Friedl and C. E. Brodley, "Decision tree classification of land cover from remotely sensed data," Remote Sensing of Environment, vol. 61, no. 3, pp. 399-409, 1997.

[55] N. R. Harvey, J. Theiler, S. P. Brumby et al., "Comparison of GENIE and conventional supervised classifiers for multispectral image feature extraction," IEEE Transactions on Geoscience and Remote Sensing, vol. 40, no. 2, pp. 393-404, 2002.

[56] G. Hong, Y. Zhang, and D. A. Lavigne, "Object-based change detection in high resolution image," in Proceedings of the American Society for Photogrammetry and Remote Sensing Annual Conference (ASPRS '06), American Society for Photogrammetry and Remote Sensing, Reno, Nev, USA, May 2006.

[57] J. V. Kaiser Jr., D. A. Stow, and L. Cao, "Evaluation of remote sensing techniques for mapping transborder trails," Photogrammetric Engineering and Remote Sensing, vol. 70, no. 12, pp. 1441-1447, 2004

[58] Visual Learning Systems, "User Manual, Feature Analyst 4.2 for ERDAS Imagine," Visual Learning Systems, Missoula, Mont, USA, p. 354, 2002, http://www.featureanalyst.com/feature_analyst/publications/manuals/FA_4.2_RELEASE/FA_4.2_ Reference_arc_040908_RELEASE.pdf.

[59] M. P. Strager, J. T. Petty, J. M. Strager, and J. Barker-Fulton, "A spatially explicit framework for quantifying downstream hydrologic conditions," Journal of Environmental Management, vol. 90, no. 5, pp. 1854-1861, 2009.

[60] M. G. Anderson, M. D. Merrill, and F. B. Biasi, Connecticut River Watershed Analysis: Ecological Communities and NeoTropical Migratory Birds (Final Report), Eastern Conservation Science, The Nature Conservancy, 1998.

[61] R. B. Grayson, I. D. Moore, and T. A. McMahon, "Physically based hydrologic modeling 1. A terrain-based model for investigative purposes," Water Resources Research, vol. 28, no. 10, pp. 2639-2658, 1992.

[62] H. Mitasova, J. Hofierka, M. Zlocha, and L. R. Iverson, "Modelling topographic potential for erosion and deposition using GIS," International Journal of Geographical Information Systems, vol. 10, no. 5, pp. 629-641, 1996. 
[63] D. M. Moore, B. G. Lees, and S. M. Davey, "A new method for predicting vegetation distributions using decision tree analysis in a geographic information system," Environmental Management, vol. 15, no. 1, pp. 59-71, 1991.

[64] M. Boer, G. Del Barrio, and J. Puigdefabregas, "Mapping soil depth classes in dry Mediterranean areas using terrain attributes derived from a digital elevation model," Geoderma, vol. 72, no. 1-2, pp. 99-118, 1996.

[65] E. M. O'Loughlin, "Prediction of surface saturation zones in natural catchments by topographic analysis," Water Resources Research, vol. 22, no. 5, pp. 794-804, 1986.

[66] A. J. Parker, "The topographic relative moisture index: an approach to soil- moisture assessment in mountain terrain," Physical Geography, vol. 3, no. 2, pp. 160-168, 1982.

[67] J. Fels and R. Zobel, "Landscape position and classified landtype mapping for the statewide DRASTIC mapping project," Tech. Rep. VEL.95.1, North Carolina State University, North Carolina Department of Environmental, Health, and Natural Resources, Division of Environmental Management, 1995.

[68] G. J. McDermid, R. J. Hall, G. A. Sanchez-Azofeifa et al., "Remote sensing and forest inventory for wildlife habitat assessment," Forest Ecology and Management, vol. 257, no. 11, pp. 2262-2269, 2009.

[69] J. R. Jensen, Introductory Digital Image Processing: A Remote Sensing Perspective, Pearson Prentice Hall, Upper Saddle River, NJ, USA, 3rd edition, 2005.

[70] D. N. Wear and R. O. Flamm, "Public and private forest disturbance regimes in the Southern Appalachians," Natural Resource Modeling, vol. 7, no. 4, pp. 379-397, 1993.

[71] D. J. Soeder, "The marcellus shale: resources and reservations," EOS Transactions American Geophysical Union, vol. 91, no. 32, pp. 277-288, 2010. 

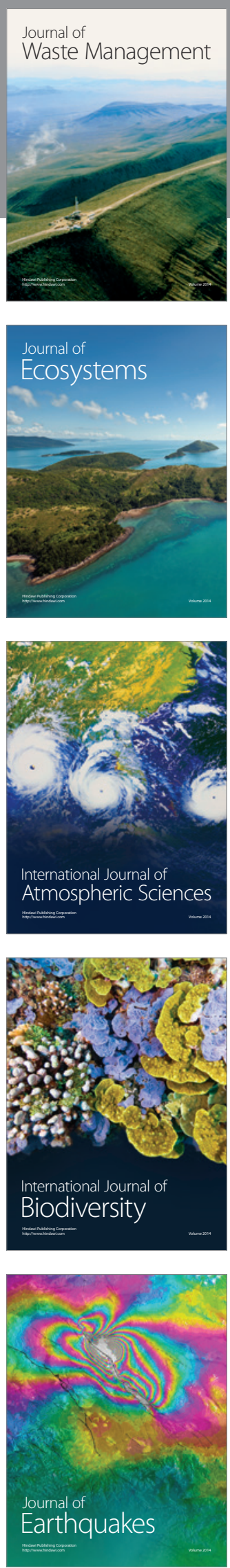
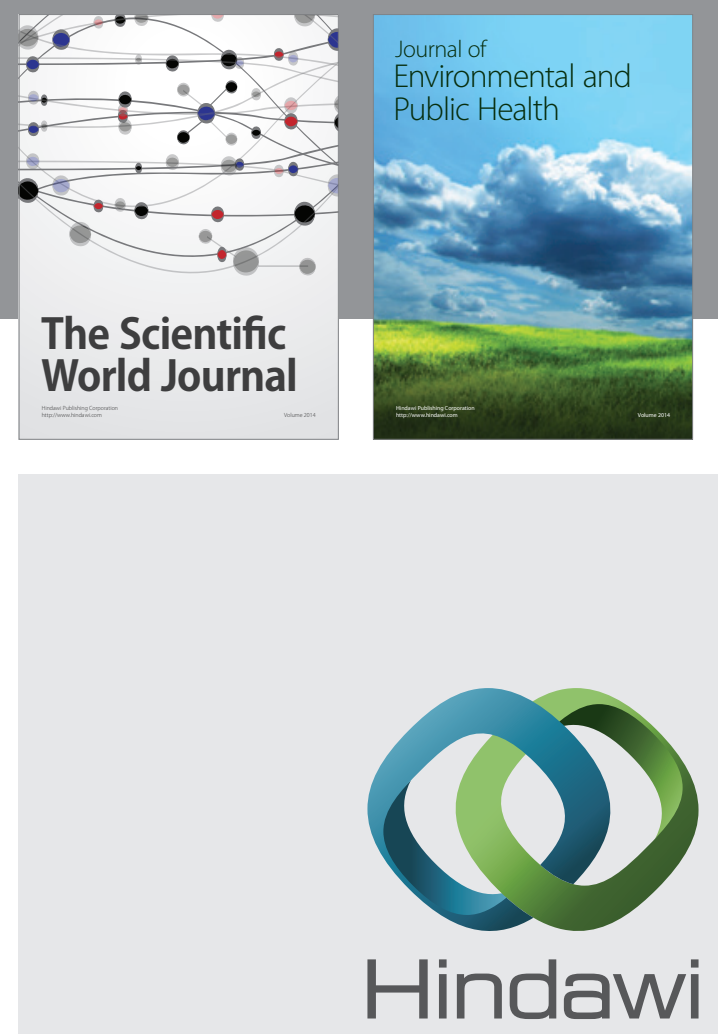

Submit your manuscripts at

http://www.hindawi.com
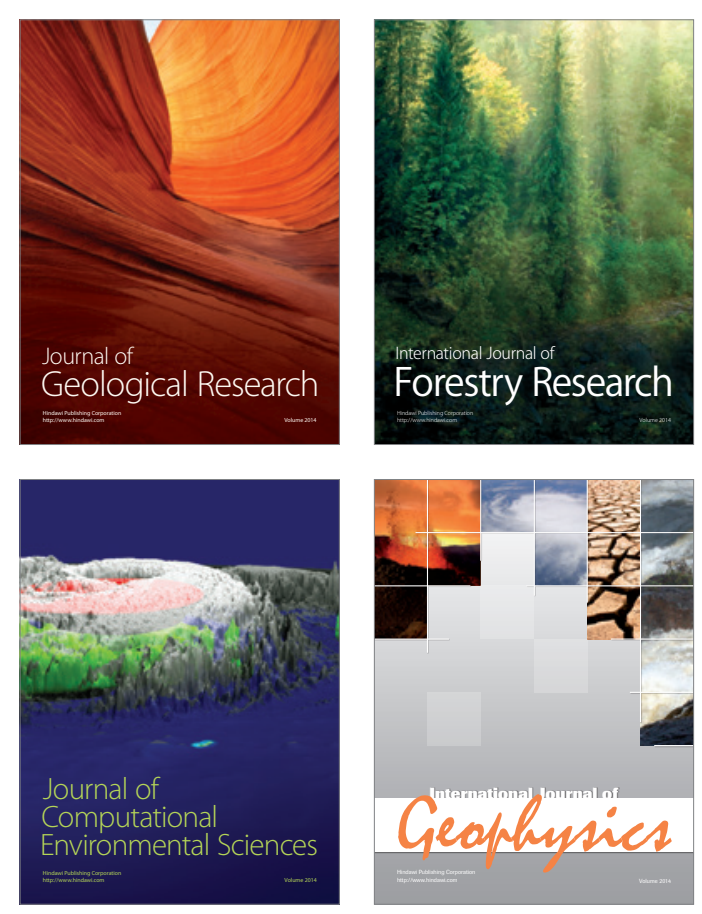
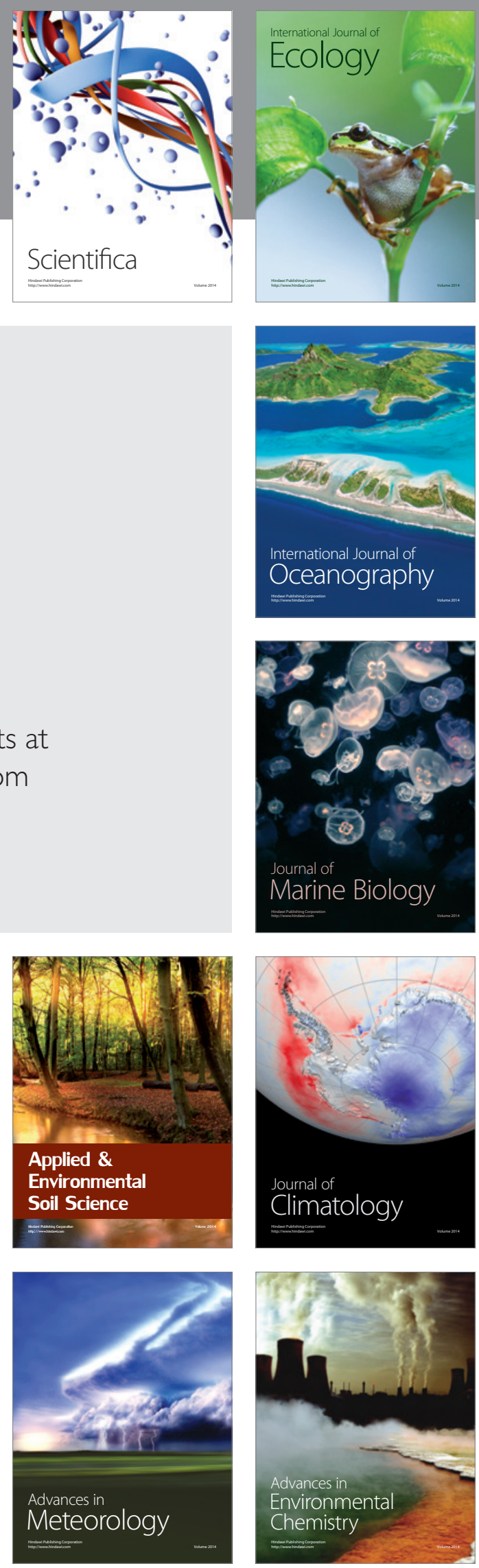